\begin{tabular}{llllllll}
$\mathbf{R}$ & $\mathbf{E}$ & $\mathbf{C}$ & $\mathbf{E}$ & $\mathbf{N}$ & $\mathbf{Z}$ & $\mathbf{J}$ & $\mathbf{E}$ \\
\hline
\end{tabular}

ROCZNIKI TEOLOGICZNE

Tom LXVIII, zeszyt $9-2021$

\author{
KS. PRZEMYSŁAW ARTEMIUK \\ Wydzial Teologiczny UKSW \\ e-mail: artemiukprzemek@gmail.com \\ DOI: https://doi.org/10.18290/rt.21689.11
}

\title{
SPÓR MAGISTERIUM KOŚCIOŁA Z MODERNIZMEM
}

PAWEŁ BORTO, Magisterium Kościoła $w$ sporze z modernizmem o fundamenty wiary. Analiza pogladów A. Loisy'ego, É. Le Roy i G. Tyrrella i ich ocena $w$ świetle dokumentów antymodernistycznych oraz Vaticanum II, Lublin: Wydawnictwo KUL 2020, ss. 353.

Praca Pawła Borto pozornie tylko jest rozprawa z zakresu historii teologii. Okazuje się bowiem, że modernizm, którym dzisiaj tak chętnie szafują środowiska tradycjonalistyczne, etykietując tym terminem teologów drugiej połowy XX i początku XXI wieku, pozostaje nadal ważnym zagadnieniem. Aktualność problematyki nie pozostawia więc najmniejszych wątpliwości.

Druga sprawa to recepcja modernizmu w Polsce. Odnoszę wrażenie, że poza hasłowymi publikacjami, pojawiającymi się w Encyklopedii Katolickiej i Leksykonie teologii fundamentalnej, nie dysponujemy systematycznymi i pogłębionymi studiami na ten temat. Paweł Borto, podejmując temat sporu Kościoła z modernizmem, nie tylko wypełnia pustą przestrzeń refleksji, jaka do tej pory istniała w polskiej literaturze teologicznej, ale daje teologom niezbędne narzędzie hermeneutyczne do zrozumienia dzisiejszych antymodernistycznych reminiscencji.

Perspektywa badawcza, przyjęta w dysertacji, jest właściwa. Paweł Borto bada modernizm obecny w teologii, ukazując go w szerokiej perspektywie historycznej, filozoficznej i teologicznej. Horyzontem analiz nie sa jedynie antymodernistyczne dokumenty Magisterium Kościoła, ale nauczanie II Soboru Watykańskiego. Uważny czytelnik z pewnością zauważy, że dopiero w świetle ostatniego soboru spór z początku XX wieku może zostać należycie oceniony. Pośpiech, poczucie zagrożenia, jakie towarzyszyło Kościołowi na przełomie XX i XXI wieku, apologetyczne nasta- 
wienie teologów i specyficzna hermeneutyka nie pozwoliły zachować odpowiedniego dystansu wobec pism modernistów i podjąć z nimi krytycznego dialogu. Po latach dopiero widać, w jakim napięciu rodziły się dokumenty wymierzone w niepokornych teologów i jaka była rzeczywista recepcja ich myśli.

Koncepcja rozprawy ujmuje logiką. Po wprowadzeniu, które Paweł Borto określa mianem prologomeny, dokonuje charakterystyki kryzysu modernistycznego. Oba rozdziały stanowią konieczne tło dla dalszych analiz. Sytuują bowiem spór z modernizmem w szerokim kontekście historyczno-filozoficzno-teologicznym. Po nakreśleniu ram Autor przechodzi do szczegółowych analiz. Z całości problemów podejmowanych przez modernistów wybiera trzy kluczowe kwestie. Są nimi Boże Objawienie, rozumienie dogmatów i pojęcie doświadczenia religijnego. Metodologia badań spornych zagadnień w każdym z trzech rozdziałów jest podobna. Najpierw kielecki teolog przedstawia rozumienie danej kwestii proponowane przez modernistów. Następnie ukazuje interwencje strony katolickiej. Na koniec spór wokół wybranego zagadnienia opisuje w horyzoncie II Soboru Watykańskiego.

Paweł Borto, analizując zmagania Kościoła katolickiego z modernizmem, sięga do oryginalnych tekstów. Są nimi pisma A. Loisy'ego, É. Le Roy i G. Tyrrella. Żaden z modernistycznych autorów nie był do tej pory tłumaczony na język polski. Praca nad źródłami, jaką podjął kielecki teolog, zasługuje na szczególne uznania. Paweł Borto nie tylko sięgnął do oryginalnych tekstów, ale także zapoznał się z licznymi komentarzami, jakich doczekały się prace modernistów. Literatura przedmiotu, jak też i same źródła zostały potraktowane wyczerpująco.

Należy zwrócić także uwagę na stronę językową rozprawy. Autor, odsłaniając rdzeń sporów, czyni to w sposób komunikatywny, zachowując w pełni naukowa narrację. Teksty oryginalne przekłada w głównym korpusie pracy, w przypisach zaś daje oryginalne fragmenty. Cechą, która wyróżnia rozprawę, są summaria, pojawiające się w zakończeniach rozdziałów. Stanowią one niezbędne podsumowanie przeprowadzonych analiz. W tych fragmentach pracy widać szczególną zdolność kieleckiego teologa do syntezy.

Książka Pawła Borto, poświęcona sporowi Magisterium Kościoła z modernizmem, jest pracą ważną i potrzebną. Odsłania istotę i historię zmagań, stanowi także niezbędne narzędzie hermeneutyczne dla interpretacji aktualnych kwestii teologicznych. 